\title{
Growth and Development of Soybean Plants with the Pat Gene under different Glufosinate Rates
}

\author{
Tamara Thaís Mundt ${ }^{1}$, Leandro Paiola Albrecht ${ }^{2}$, Alfredo Junior Paiola Albrecht ${ }^{2}$, Fábio Henrique Krenchinski ${ }^{1}$, \\ Vinícius Gabriel Caneppele Pereira1, Felipe Gustavo Wagner ${ }^{2}$, André Felipe Moreira Silva ${ }^{3^{*}}$ and Caio Antonio \\ Carbonari $^{1}$ \\ 'São Paulo State University, School of Agriculture, Botucatu, São Paulo, Brazil \\ ${ }^{2}$ Federal University of Paraná, Palotina, Paraná, Brazil \\ ${ }^{3}$ Crop Science, Palotina, Paraná State, Brazil \\ *For correspondence: afmoreirasilva@hotmail.com \\ Received 05 January 2021; Accepted 14 April 2021; Published 10 July 2021
}

\begin{abstract}
The pat gene confers tolerance to glufosinate in transgenic soybean plants; however, some aspects of the selectivity of this herbicide need to be better elucidated. This study aimed to evaluate the development of soybean plants with the pat gene under the application of different glufosinate rates. The experiment was conducted in a greenhouse and included seven different glufosinate rates of and two soybean cultivars (LL0291 and LL0767) with the pat gene, with four replications in a completely randomized design. Glufosinate was applied at the V4 stage (4 nodes on the main stem with fully developed leaves beginning with the unifoliolate nodes) of soybean, and the variables analyzed were: soybean injury, chlorophyll index, plant height, dry and fresh matter of shoots and roots, wet nodules, dry nodules, and total number of nodules. It was found that for both cultivars, the maximum recommended glufosinate rate of $700 \mathrm{~g}$ of active ingredient (ai) ha ${ }^{-1}$ was safe, rates above $1,250 \mathrm{~g}$ ai $\mathrm{ha}^{-1}$ may interfere with development, especially biomass accumulation, and, in general, cultivar LL0291 exhibited more injuries than cultivar LL0767. The glufosinate-tolerant soybean (with pat gene) is a great option for farmers, but care should be taken with respect to rates above the maximum recommended in the package insert, so that there is no damage to soybean. (C) 2021 Friends Science Publishers
\end{abstract}

Keywords: Glycine max L.; Crop injury; Liberty link ${ }^{\circledR}$; Chlorophyll indices; Selectivity

\section{Introduction}

Soybean (Glycine max [L.] Merrill) was introduced in Brazil in the late $19^{\text {th }}$ century, especially in the late $1940 \mathrm{~s}$. Soybeans are of great importance, not only in Brazil, but also in the worldwide agricultural production system. In Brazil, it occupies a prominent position and is the most important culture in grain production and export. Soybean is considered one of the main sources of vegetable oils and proteins for human and animal food. It is a vital product in the Brazilian economy, especially for the supply of oil for domestic consumption, animal feed as the main protein source, and biofuel production (Sediyama et al. 2009; Freitas and Mendonça 2016). In this context, research on this activity aims to increase profitability. Therefore, the use of transgenic cultivars and herbicides to control weeds is worth mentioning.

The herbicide glufosinate is classified as nonselective; it inhibits the activity of the glutamine synthetase (GS) enzyme. The GS enzyme detoxifies ammonia and produces amino acid glutamine from ammonia and glutamate (Barnett et al. 2012). Glufosinate comes from the natural toxin (phosphinothricin) of the fungi Streptomyces viridochromogenes and S. hygroscopicus (Dayan and Duke 2014; ISAAA 2021).

After the application of glufosinate, susceptible plants display glutamine deficiency, intoxication due to the accumulation of ammonia and glyoxylate, disruption of the chloroplast structure, concomitant with a reduction in electron flow and inhibition of photosynthesis (Dayan et al. 2015; Carbonari et al. 2016). Thus, glufosinate interferes with chlorophyll content and the assimilation of nitrogen by plants.

The pat gene comes from $S$. viridochromogenes, when transcribed in the plant, produces the phosphinothricin acetyltransferase (PAT) enzyme, which has the capacity to metabolize glufosinate into N-acetyl-L-glufosinate (NAG). This compound is non-toxic to plants and does not inhibit GS enzymes (Herouet et al. 2005; Tan et al. 2006). This gene is present in transgenic events at soybean, maize and cotton, conferring tolerance to glufosinate. Transgenic Liberty Link $^{\circledR}$ (LL) soybean, A2704-12 and A5547-127

To cite this paper: Mundt TT, LP Albrecht, AJP Albrecht, FH Krenchinski, VGC Pereira, FG Wagner, AFM Silva, CA Carbonari (2021). Growth and development of soybean plants with the Pat gene under different glufosinate rates. Intl J Agric Biol 26:217-223 
events, are tolerant to glufosinate due to the insertion of this gene (ISAAA 2021; Albrecht et al. 2021).

In other crops tolerant to glufosinate with either the pat or bar genes, as in the case of maize and cotton, the application of this herbicide can lead to the appearance of visual injuries, reduced electron transport flow and ammonia accumulation, among other factors (Carbonari et al. 2016; Silva et al. 2016; Krenchinski et al. 2018a). In soybean, the application of glufosinate at $450 \mathrm{~g}$ active ingredient (ai) ha ${ }^{-1}$ did not cause a reduction in chlorophyll, biomass accumulation, nodule mass, or yield (Reddy et al. 2011). Kaur et al. (2014) reported injury to soybean of up to $10 \%$ for glufosinate application (594 $\left.\mathrm{g} \mathrm{ai} \mathrm{ha}^{-1}\right)$, in different mixtures with other herbicides.

The insertion of the pat gene allows applications of glufosinate on LL soybean at rates up to three times higher than that recommended for use in the field (CTNB 2010). The maximum recommended rate in the package insert for glufosinate application in LL soybean is $700 \mathrm{~g}^{\text {ai }} \mathrm{ha}^{-1}$ (Rodrigues and Almeida 2018). However, even with the tolerance of LL soybean to glufosinate, there is little literature on amounts that can cause harmful effects.

High rates of glufosinate can be applied to the field by farmers. However, studies on the effects of high rates of glufosinate are scarce, on development, chlorophyll, biomass accumulation, and biological nitrogen fixation in soybeans. It is believed that high rates of glufosinate may affect these aspects of soybean. Thus, this study aimed to evaluate the development, chlorophyll, biomass accumulation, and nodule development of glufosinatetolerant soybean cultivars (with the pat gene) after application of the herbicide glufosinate.

\section{Materials and Methods}

\section{Experimental setup}

The experiment was conducted in a greenhouse in Palotina, state of Paraná (PR), Brazil (24¹7'45.1" S, 5050’35.4" $\mathrm{W})$. The temperature was maintained at an average of $25^{\circ} \mathrm{C}$ \pm 2 , with an irrigation of $5 \mathrm{~mm} \mathrm{day}^{-1}$ and an average photoperiod of $12 \mathrm{~h}$, from March to May 2017. The test was conducted in 5-liter pots containing soil collected at a depth of 0-20 cm. The soil was classified as clayey (clay: $63.75 \%$; sand: $17.5 \%$; silt: $18.75 \%)$, had a $\mathrm{pH}\left(\mathrm{CaCl}_{2}\right): 5.3$ and CEC: $17.74 \mathrm{cmol}^{\mathrm{dm}}{ }^{-3}$.

\section{Experimental design}

A completely randomized design (CRD) was used in a $2 \times 7$ factorial arrangement (cultivars $\times$ rates), with four repetitions. The two soybean cultivars used were: LL0291 and LL0767 (non-commercial lines - event A5547-127) and seven rates $\left(0,250,500,750,1,000,1,250\right.$ and $\left.1,500 \mathrm{~g}^{\text {ai }} \mathrm{ha}^{-1}\right)$ of glufosinate (Liberty ${ }^{\circledR}$, Bayer S.A.). Five soybean seeds were sown per pot, and at 7 days after emergence, the pots were thinned to two plants per unit.
Herbicide was applied at the V4 stage (4 nodes on the main stem with fully developed leaves beginning with the unifoliolate nodes) of soybean plants using a $\mathrm{CO}_{2}$ pressurized backpack sprayer at a constant pressure of 2 bars. The flow rate was $0.65 \mathrm{~L} \mathrm{~min}^{-1}$, in a bar containing six fan nozzles (XR 110 02, Teejet), at a speed of $1 \mathrm{~m} \mathrm{~s}^{-1}$, with a $50 \mathrm{~cm}$ wide application range per nozzle, providing a spray volume of $150 \mathrm{~L} \mathrm{ha}^{-1}$. The application was carried out at a temperature of $25.2^{\circ} \mathrm{C}$ and relative humidity of $80.3 \%$.

\section{Data collection}

The chlorophyll index and crop injury to soybean plants were measured 4, 7, 14, 21, 28 and 35 days after application (DAA). The chlorophyll index was evaluated in the central leaflet of the third fully expanded trifoliate leaf of the two plants in each pot, considering the count from top to bottom. Chlorophyll indices were measured using an electronic chlorophyll meter (ClorofiLOG - CFL1030, Falker Automação Agrícola Ltd.) as reported (Júnior et al. 2012). Visual crop injury scores were attributed to soybean plants after the application of glufosinate. These assessments were carried out through visual analysis at each experimental unit considering significantly visible symptoms at soybean plants, according to their development. Scores from 0 to $100 \%$ were assigned, where 0 represented the absence of symptoms and $100 \%$ the death of the plant (Velini et al. 1995). The glufosinate rate $0 \mathrm{~g}$ ai ha $^{-1}$ (without herbicide effect) was used as a reference for evaluations, always with a score of 0 , for injuries to soybean plants.

Plant height was measured with the aid of a measuring tape and the plants were measured from the last fully expanded trifoliate leaf to the ground surface. These analyses were performed $0,4,7,14,21,28,35$ and 42 DAA.

At the end of the experiment (42 DAA), the shoots and roots of the plants were collected to study the fresh and dry matter of the root and shoot. After cutting the plant material from the shoot, the soil with the roots was removed from each pot, carefully with the aid of running water and sieves. In addition to these evaluations, nodules of nitrogen-fixing bacteria present in the roots were collected, counted, weighed, and then dried. The shoots and roots of the plants were stored in paper bags and dried in forced air circulation $\left(60^{\circ} \mathrm{C}\right.$ to constant weight). Then, each part of the plant was weighed on a precision scale $(0.0001 \mathrm{~g})$, and the weight values were expressed in percentage relative to the values of rate 0 (control).

\section{Statistical analysis}

After checking the assumptions, no data transformation it was required. The data were subjected to analysis of variance (ANOVA) $(P \leq 0.05)$. For the factor glufosinate rates, the data were subjected to regression analysis $(P \leq$ 0.05). For the factor soybean cultivars, the data were 
compared using the F-test $(P \leq 0.05)$. All necessary breakdowns have been made (Pimentel-Gomes and Garcia 2002). For ANOVA, the Sisvar 5.6 software was used (Ferreira 2011). For regression analysis, the SigmaPlot 13 software was used.

In the model selection at regression analysis, the following fit quality parameters were adopted: significant regression, regression deviations or lack of adjustment, significant t-test for all regression coefficients, residue analysis without trend, low coefficient of variation, high R, and biological explanation. To create the Figs, the Microsoft 365 Excel software was used.

\section{Results}

There was no significant effect $(P>0.05)$ on the chlorophyll indices of either factor. For crop injury, no significant effect was observed for cultivar $(P>0.05)$ at $4,7,14,21,28$ and 35 DAA; for all crop injury assessments the variation in rates had a significant effect $(P \leq 0.05)$. For height, there was no significant effect $(P>0.05)$ on cultivar at 7 and 14 DAA, while in the other assessments effect was significant $(P \leq 0.05)$. For height, a significant effect $(P \leq 0.05)$ was observed only at 7 and 14 DAA. For the assessments related to the nodules, no significant effect was detected $(P>0.05)$ for either factor. For dry and fresh shoot matter, a significant effect $(P \leq 0.05)$ was found for both factors. For root weight, no significant effect $(P>0.05)$ was observed for the factor cultivar only in the case of dry matter (Table 1).

An increasing linear fit of the rates of glufosinate it was adjusted for crop injury, with values of up to $26.25 \%$ for the highest rate. With increasing rates, an increase in symptoms was observed. Among the cultivars, differences were found only at $14 \mathrm{DAA}$, with a higher percentage in cultivar LL0291 for the application of $500 \mathrm{~g}$ ai ha ${ }^{-1}$ (Fig. 1).

For height, it was observed that cultivar LL0291 was inferior to cultivar LL0767, with a difference on the day of application as well as at 4, 21, 28, 35 and 42 DAA. This can be explained by the specific differences of each cultivar; from the beginning of the assessments, it was observed that cultivar LL0291 had shorter heights than cultivar LL0767 (Fig. 2). The two cultivars have an indeterminate cycle, that is, with no exact growth parameters. At 7 and 14 DAA, an effect of rate of application was observed on height for cultivar LL0291 - a reduction in height was observed with increasing rates, with linear fit (Fig. 3).

For fresh shoot matter, a polynomial fit of glufosinate rates it was adjusted, with cultivar LL0767 being superior at a rate of $1,000 \mathrm{~g}$ ai ha ${ }^{-1}$, similar to that observed for shoot dry matter. For fresh root matter, a decreasing linear fit was possible with increasing rates for cultivar LL0291. A polynomial fit was possible for the cultivar LL0767. Comparison between cultivars showed that LL0767 was superior to LL0291 at rates of 750 and 1,250 $\mathrm{g}$ ai ha ${ }^{-1}$. For root dry matter, no differences were detected between cultivars, with a decreasing linear fit with increasing rates of glufosinate (Fig. 4). In this sense, it is emphasized that the maximum recommended rate of glufosinate for postapplication in LL soybean plants is $700 \mathrm{~g}^{\text {ai }} \mathrm{ha}^{-1}$, on the package insert (Rodrigues and Almeida 2018).

\section{Discussion}

The scores for crop injury assessments gradually decreased, showing a good recovery capacity for both cultivars. The insertion of the pat gene confers a great tolerance to glufosinate (Silva et al. 2017; Krenchinski et al. 2018b; Albrecht et al. 2020), which was also observed in this study. This gene encodes the PAT enzyme, which detoxifies glufosinate in NAG in transgenic plants. The NAG compound does not inhibit the GS enzyme, which explains the tolerance of plants, with the pat gene, to glufosinate (Müllner et al. 1993). Carbonari et al. (2016) compared two cotton cultivars containing the pat gene (FM 975WS and IMACD 6001LL) and observed that cultivar FM 975WS had much lower levels of the pat gene, which means that the rates supported by this cultivar were lower than those supported by cultivar IMACD 6001LL.

In another study, in LL soybean, injury of $15 \%$ was observed for the glufosinate $\left(740 \mathrm{~g}\right.$ ai ha $\left.^{-1}\right)$ applied at the V2 stage, with sequential application at V6 (593 $\mathrm{g}$ ai ha ${ }^{-1}$ ) (Aulakh and Jhala 2015). Albrecht et al. (2020) observed that application of glufosinate (at 2,800 $\mathrm{g}$ ai ha ${ }^{-1}$ ), which was up to four times the maximum recommended, caused crop injury (up to $38.5 \%$ ) in soybean plants, but soybean yield remained unaffected. Other studies have not observed significant injury in LL soybean plants (Johnson et al. 2014; Chahal and Jhala 2015; Schultz et al. 2015) or have observed injury (up to $13 \%$ ) mainly in mixtures with other herbicides, but always without a reduction in yield (Striegel et al. 2020). Thus, glufosinate had no effect on the crop yield. The deleterious effects, in some aspects, are generally observed at rates above the recommended value. Similar to that observed in the present study, in which the application of glufosinate was selective up to the maximum recommended rate, with deleterious effects at higher rates.

Nitrogen assimilation is one of the most important functions of the cell, and GS is an important enzyme in the assimilation of ammonia. GS is inhibited by the action of glufosinate, with a rapid accumulation of ammonia, which is related to the destruction of chloroplasts, reduced levels of photosynthesis, and decreased production of amino acids (Brunharo et al. 2014). In a study that compared the effect of rates of glufosinate in soybeans with and without pat genes, it was observed that ammonia accumulation increased with increasing rate, with greater accumulation in soybeans without the pat gene (Albrecht et al. 2020). However, other study reported that ammonia accumulation in plant tissues due to the inhibition of glutamine synthetase is not enough to cause injury to plant tissues. However, inhibition of glutamine synthetase rapidly increases the levels of reactive oxygen species that are extremely 
Mundt et al. / Intl J Agric Biol, Vol 26, No 2, 2021

Table 1: Significance results of the analysis of variance (by F-test), for all variables analyzed

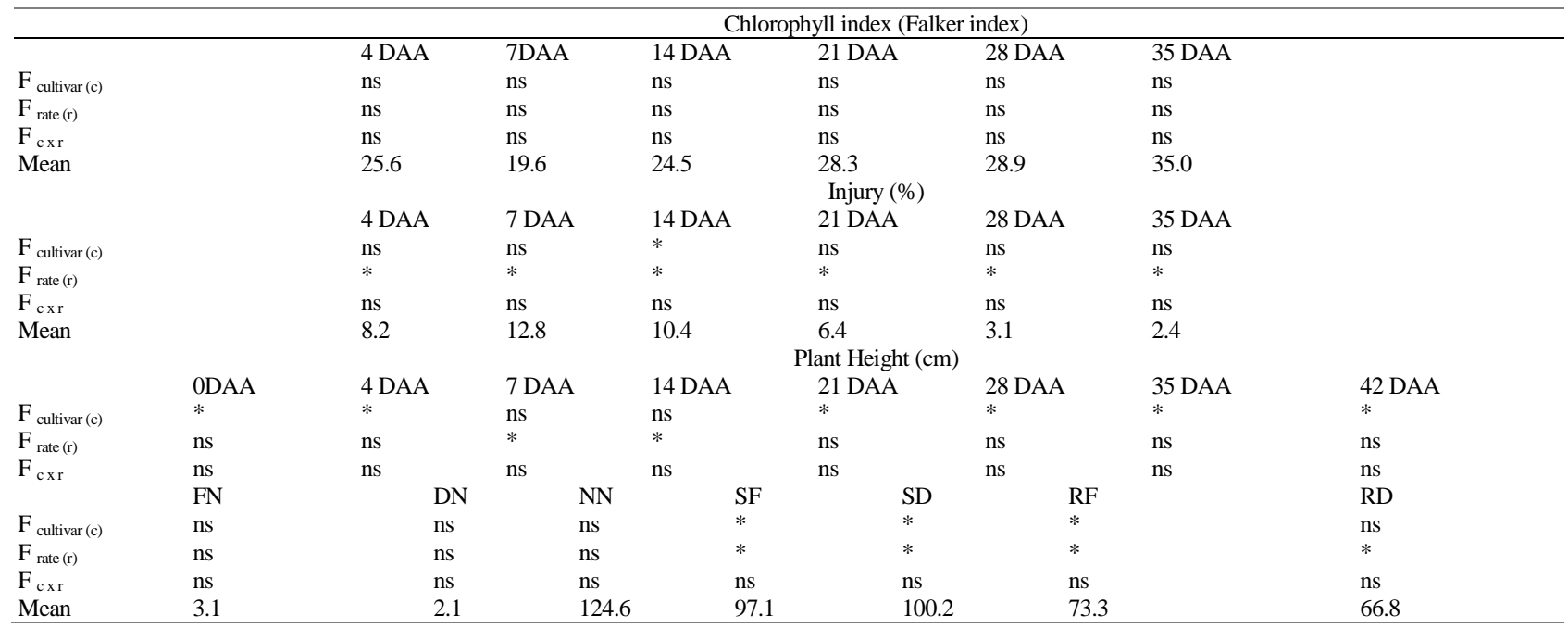

DAA: days after application; FN: fresh nodules mass (g); DN: dry nodules mass (g); NN: number of nodules; SF: shoot fresh mass (\%); SD: shoot dry mass (\%); RF: root fresh mass (\%); RD: root dry mass (\%)

*Significant $(P \leq 0.05)$, means differ each other by F-test. ${ }^{\text {ns }}$ : Non-significant $(P>0.05)$, means do not differ each other by F-test
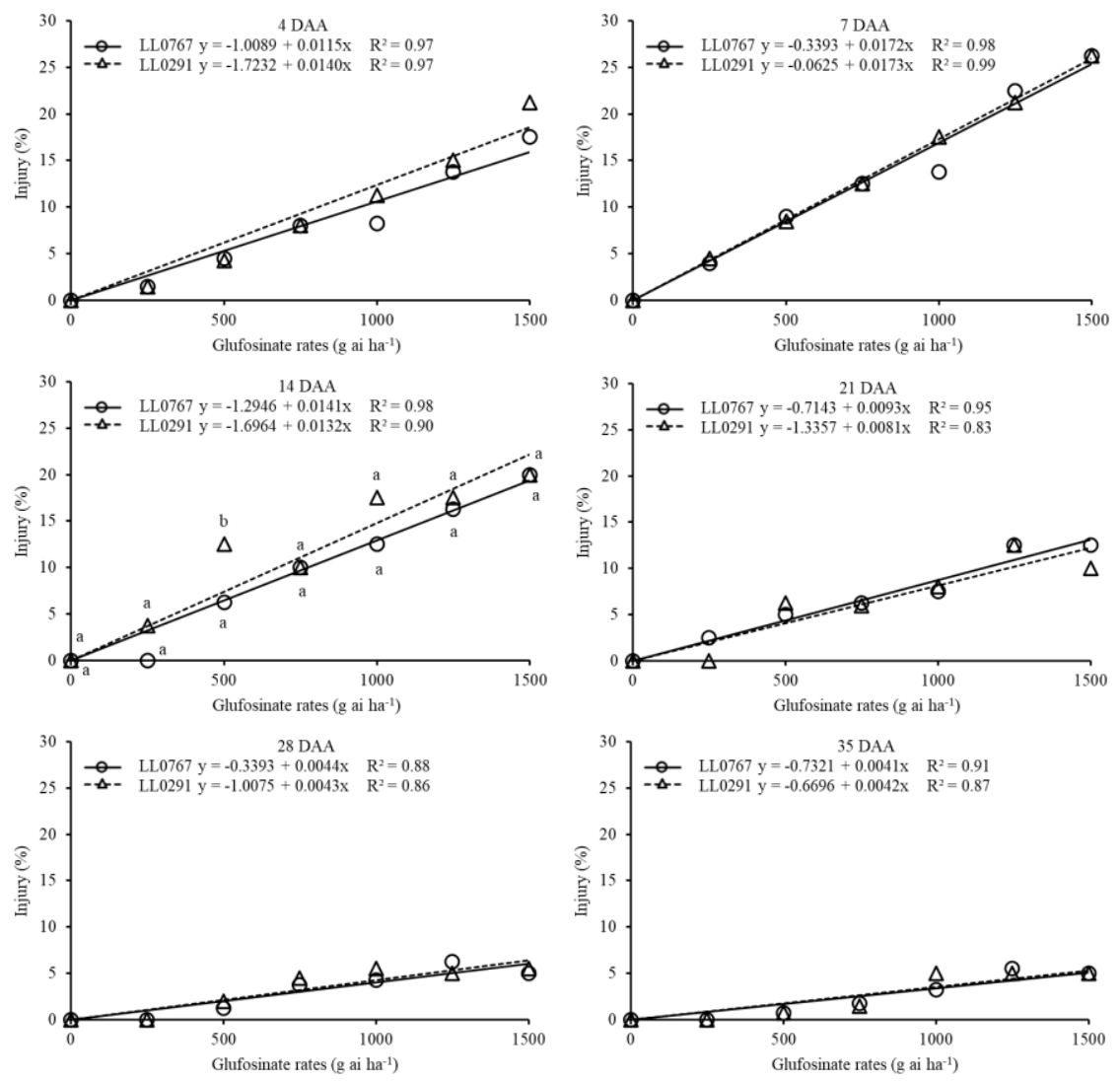

Fig. 1: Increasing linear fit for injury soybean cultivars with the pat gene (LL0767 and LL0291), at 4, 7, 14, 21, 28 and 35 days after application of glufosinate rates. Palotina, PR, Brazil, 2017

At 14 DAA, means followed by the same letter, when comparing cultivars, do not differ by the F-test $(P \leq 0.05)$. At other dates, for cultivars, means do not differ each other by F-test $(P>0.05)$

phytotoxic and cause loss of membrane integrity due to lipid peroxidation (Takano et al. 2019).

Regarding the development of soybean plants, regarding nodules, no effect due to glufosinate rates was observed. Few studies have evaluated the development of soybean nodules under the application of glufosinate. With 


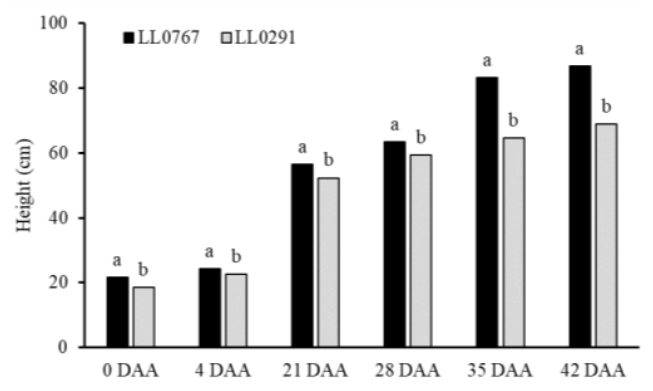

Fig. 2: Height of soybean plants (cm) with the pat gene (LL0767 and LL0291) under rates of glufosinate at 0, 4, 28, 35 and 42 days after application (DAA). Palotina, PR, Brazil, 2017

Means followed by the same letter, when comparing cultivars, on each evaluation date, do not differ by the F-test $(P \geq 0.05)$
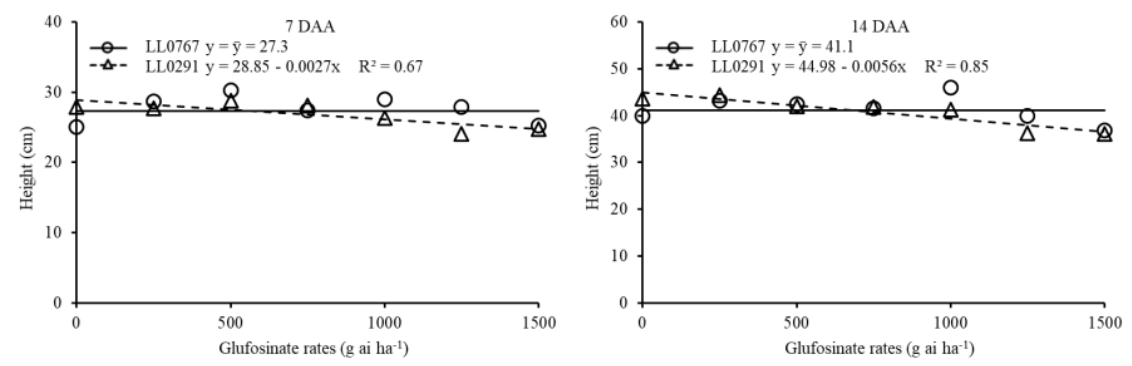

Fig. 3: Height of soybean plants (cm) with the pat gene (LL0767 and LL0291), under glufosinate rates at 7 and 14 days after application (DAA), with decreasing linear fit at LL0291 cultivar. Palotina, PR, Brazil, 2017

For cultivars, means do not differ each other by F-test $(P>0.05)$
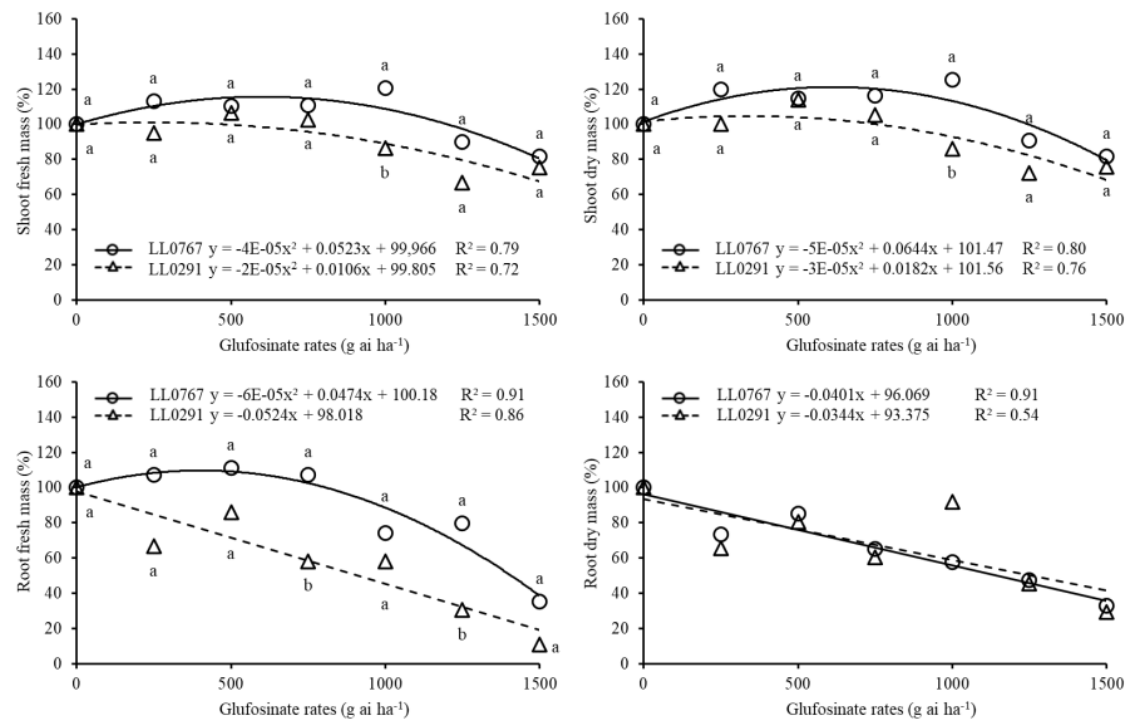

Fig. 4: Mass (\%) of soybean cultivars with the pat gene (LL0767 and LL0291) under glufosinate rates. Palotina, PR, Brazil, 2017 Polynomial fit at shoot fresh mass, shoot dry mass, and root fresh mass (LL0767) Decreasing linear fit at root fresh mass (LL0291) and root dry mas

For cultivars, at root dry mass, means do not differ with each other by F-test $(P>0.05)$, at other variables, means followed by the same letter, do not differ by the F-test $(P \leq 0.05)$

respect to the mass of the shoots and roots, reductions were observed, especially at high rates. This is similar to observations by Garcia et al. (2020), who analyzed the quality of seeds produced from soybeans with the pat gene, in which the application of glufosinate $\left(500 \mathrm{~g}\right.$ ai ha $\left.{ }^{-1}\right)$ at the V6 soybean stage reduced the shoot mass of the seedlings.
In the present study, the chlorophyll indices of LL soybeans were not affected by the application of glufosinate. Similarly, Kita et al. (2009) found no reduction in the chlorophyll index (SPAD index) for the application of glufosinate in soybean. Information on chlorophyll indices in LL soybeans is scarce. In other genetically modified 
crops that are tolerant to glufosinate (such as maize with the pat gene), no reductions in chlorophyll indices have been reported for glufosinate application (Krenchinski et al. 2018a).

For chlorophyll content, Reddy et al. (2011) did not find a reduction in LL soybean upon glufosinate application $\left(450+450 \mathrm{~g}\right.$ ai ha $\left.{ }^{-1}\right)$ post-emergence (V3-V4 + V7-V8). In the same study, the authors observed a crop injury of $3 \%$, with no reduction in soybean yield. This is one of the few studies reporting the effects of glufosinate in commercial soybean cultivars (with the pat gene). This highlights the importance of the results observed in this study, indicating the selectivity of the herbicide for soybean LL, especially considering that in the coming years, Enlist ${ }^{\mathrm{TM}} \mathrm{E} 3$ soybean (with the pat gene) may be commercially available, and this technology also has a tolerance to glufosinate.

\section{Conclusion}

Glufosinate rates above $1,250 \mathrm{~g}$ ai ha ${ }^{-1}$ may interfere with development (especially biomass accumulation), of soybean with the pat gene. The maximum recommended rate of 700 $\mathrm{g}$ ai ha ${ }^{-1}$ was safe for soybean plants with the pat gene. Recovery capacity was observed in both, showing high selectivity in glufosinate for soybean genotypes with the pat gene. Soybean with the pat gene is an alternative for farmers in the alternation of technologies and consequently, the rotation of mechanisms of action of herbicides.

\section{Acknowledgments}

Thanks to the Supra Pesquisa team from the Federal University of Paraná, for operational support in the implementation of activities.

\section{Author Contributions}

TTM, LPA, AJPA and CAC conceived and designed the study. TTM, FHK, VGCP and FGW collected study data. TTM and AFMS analyzed the data and wrote the original version of the manuscript. All authors critically revised the manuscript for important intellectual contents and approved the final version.

\section{Conflict of Interest}

The authors declare that they have no conflict of interest.

\section{Data Availability}

The data will be made available on acceptable requests to the corresponding author.

\section{Ethics Approval}

Not applicable.

\section{References}

Albrecht LP, AJP Albrecht, AFM Silva, AAM Barroso (2021). Manejo de organismos geneticamente modificados tolerantes a herbicidas. In: Matologia: Estudos Sobre Plantas Daninhas, pp:506-547. Barroso AAM, T Murata (Eds). Fábrica da Palavra, Jaboticabal, SP, Brazil

Albrecht AJP, IPF Brito, LP Albrecht, AFM Silva, AKA Matos, CA Carbonari, ED Velini (2020). Metabolic changes, agronomic performance, and quality of seeds in soybean with the pat gene after application of glufosinate. Weed Sci 68:594-604

Aulakh JS, AJ Jhala (2015). Comparison of glufosinate-based herbicide programs for broad-spectrum weed control in glufosinate-resistant soybean. Weed Technol 29:419-430

Barnett KA, TC Mueller, LE Steckel (2012). Glyphosate-resistant giant ragweed (Ambrosia trifida) control in WideStrike ${ }^{\circledR}$ flex cotton. Weed Technol 26:611-616

Brunharo CACG, PJ Christoffoleti, M Nicolai (2014). Aspectos do mecanismo de ação do amônio glufosinato: Culturas resistentes e resistência de plantas daninhas. Rev Bras Herb 13:163-177

Carbonari CA, DO Latorre, GL Gomes, ED Velini, DK Owens, Z Pan, FE Dayan (2016). Resistance to glufosinate is proportional to phosphinothricin acetyltransferase expression and activity in LibertyLink $®$ and WideStrike $®$ cotton. Planta 243:925-933

Chahal PS, AJ Jhala (2015). Herbicide programs for control of glyphosateresistant volunteer corn in glufosinate-resistant soybean. Weed Technol 29:431-443

CTNB - Comissão Técnica Nacional de Biossegurança () (2010). Technical Report n 2273.2010, CTNBio, Brasília, DF, Brazil

Dayan FE, SO Duke (2014). Natural compounds as next-generation herbicides. Plant Physiol 166:1090-1105

Dayan FE, DK Owens, N Corniani, FML Silva, SB Watson, JL Howell, DL Shaner (2015). Biochemical markers and enzyme assays for herbicide mode of action and resistance studies. Weed Sci 63:23-63

Ferreira DF (2011). Sisvar: A computer statistical analysis system. Cienc Agrotecnol 35:1039-1042

Freitas RE, MAA Mendonça (2016). Expansão agrícola no Brasil e a participação da soja: 20 anos. Rev Econ Sociol Rur 54:497-516

Garcia JR, AAM Vargas, LT Perboni, EA Souza, D Tessaro, FR Lucio, D Agostinetto (2020). Physiological attributes of Enlist E3 ${ }^{\mathrm{TM}}$ soybean seed submitted to herbicides application. Plant Danin 38; Article e020220418

Herouet C, DJ Esdaile, BA Mallyon, E DeBruyne, A Schulz, T Currier, K Hendrickx, RJ van der Klis, D Rouan (2005). Safety evaluation of the phosphinothricin acetyltransferase proteins encoded by the pat and bar sequences that confer tolerance to glufosinate-ammonium herbicide in transgenic plants. Regul Toxicol Pharmacol 41:134-149

ISAAA - International Service for the Acquisition of Agri-biotech Applications (2021). GM Crop Events approved in Brazil. Available at: http://www.isaaa.org/gmapprovaldatabase/ (Accessed: 17 Jan 2021)

Johnson DB, JK Norsworthy, RC Scott (2014). Herbicide programs for controlling glyphosate-resistant johnsongrass (Sorghum halepense) in glufosinate-resistant soybean. Weed Technol 28:10-18

Júnior E, ROP Rossiello, RVMM Silva, RC Ribeiro, MJF Morenz (2012). A new chlorophyll meter to estimate chlorophyll contents in leaves of Tifton 85 bermudagrass. Cienc Rur 42:2242-2245

Kaur S, LD Sandell, JL Lindquist, AJ Jhala (2014). Glyphosate-resistant giant ragweed (Ambrosia trifida) control in glufosinate-resistant soybean. Weed Technol 28:569-577

Kita Y, MS Hanafy, M Deguchi, H Hasegawa, T Terakawa, K Kitamura, M Ishimoto (2009). Generation and characterization of herbicideresistant soybean plants expressing novel phosphinothricin Nacetyltransferase genes. Breed Sci 59:245-251

Krenchinski FH, AJP Albrecht, VJS Cesco, DM Rodrigues, VGC Pereira, LP Albrecht, CA Carbonari, RV Filho (2018a). Post-emergent applications of isolated and combined herbicides on corn culture with cp4-epsps and pat genes. Crop Prot 106:156-162

Krenchinski FH, CA Carbonari, VJS Cesco, AJP Albrecht, MCL Arcuri, IG Maia, ED Velini (2018b). Glufosinate resistance level is proportional to phosphinothricin acetyltransferase gene expression in glufosinateresistant maize. J Agric Food Chem 66:12641-12650 


\section{Soybean Expressing Pat Gene under Glufosinate Application / Intl J Agric Biol, Vol 26, No 2, 2021}

Müllner H, P Eckes, G Donn (1993). Engineering crop resistance to the naturally occurring glutamine synthetase inhibitor phosphinothricin In: Pest Control with Enhanced Environmental Safety (ACS Symposium Series 524), pp:38-47. Duke SO, JJ Menn, JR Plimmer JR (Eds). American Chemical Society, Washington, DC, USA

Pimentel-Gomes F, CH Garcia (2002). Estatística Aplicada a Experimentos Agronômicos e Florestais: Exposição Com Exemplos e Orientações Para uso de Aplicativos. Fealq, Piracicaba, SP, Brazil

Reddy KN, RM Zablotowicz, N Bellaloui, W Ding (2011). Glufosinate effects on nitrogen nutrition, growth, yield, and seed composition in glufosinate-resistant and glufosinate-sensitive soybean. Intl J Agron 2011; Article 109280

Rodrigues BN, FS Almeida (2018). Guia de herbicidas, $7^{\text {th }}$ edn, pp:137142. Londrina, PR, Brazil

Sediyama T, RC Teixeira, HB Barros (2009). Tecnologias de Produção e usos da Soja. Mecenas, Londrina, PR, Brazil

Silva AFM, AJP Albrecht, BF Giovanelli, GA Ghirardello, VW Damião, LP Albrecht, RV Filho (2017). Seletividade de herbicidas isolados e em associações para milho RR2/LL®. Rev Bras Herb 16:60-66
Silva IPF, CA Carbonari, ED Velini, JFS Junior, L Tropaldi L, GLGC Gomes (2016). Absorption velocity of glufosinate and its effects on weeds and cotton. Agrociencia 50:239-249

Schultz JL, DB Myers, KW Bradley (2015). Influence of soybean seeding rate, row spacing, and herbicide programs on the control of resistant waterhemp in glufosinate-resistant soybean. Weed Technol 29:169-176

Striegel A, KM Eskridge, NC Lawrence, SZ Knezevic, GR Kruger, CA Proctor, AJ Jhala (2020). Economics of herbicide programs for weed control in conventional, glufosinate, and dicamba/glyphosate-resistant soybean across Nebraska. Agron J 112:5158-5179

Takano HK, R Beffa, C Preston, P Westra, FE Dayan (2019). Reactive oxygen species trigger the fast action of glufosinate. Planta 249:1837-1849

Tan S, R Evans, B Singh (2006). Herbicidal inhibitors of amino acid biosynthesis and herbicide-tolerant crops. Amino Acids 30:195-204

Velini ED, R Osipe, DLP Gazziero (1995). Procedimentos Para Instalação, Avaliação e Análise de Experimentos Com Herbicidas. SBCPD, Londrina, PR, Brazil 